\title{
A new species of Babycurus Karsch, 1886 from northern Cameroon (Scorpiones: Buthidae)
}

\author{
Новый вид рода Babycurus Karsch, 1886 из Северного Камеруна \\ (Scorpiones: Buthidae)
}

\author{
Wilson R. Lourenço \\ Вимьсон Моуренсо
}

Muséum national d'Histoire naturelle, Département Systématique et Evolution, UMR7205, CP 053, 57 rue Cuvier, 75005 Paris, France

KEY WORDS: Scorpiones, Buthidae, Babycurus, new species, Cameroon, savannah.

КЛЮЧЕВЫЕ СЛОВА: Scorpiones, Buthidae, Babycurus, новый вид, Камерун, саванна.

ABSTRACT. A new scorpion species, Babycurus prudenti sp.n., is described from the region of Garoua in the North of Cameroon. The new species is characterized by a smaller total body size as compared to the other species of the genus, and a general golden-yellow to orange-testaceous coloration with some very diffuse fuscosity. This species, a possible endemic element from the savannah formations of northern Cameroon, provides further evidence regarding the unsuspected scorpion richness of this region.

РЕЗЮМЕ. Описан новый вид скорпиона Babycurus prudenti sp.n. из района Гаруа на севере Камеруна. Новый вид характеризуется меньшими общими размерами тела по сравнению с другими видами рода, а также золотисто- до оранжево-желтой общей окраской с некоторым очень рассеянным затемнением. Этот вид, возможно, эндемичный реликт саванновых формаций Северного Камеруна, который проливает новый свет на неожиданно высокое богатство фауны скорпионов данного района.

\section{Introduction}

Several studies have dealt with the scorpions of Cameroon and adjacent countries, leading to descriptions of new species such as Babycurus johnstonii Pocock, 1896 or new records in western Africa, (e.g. Opisthacanthus lecomtei (Lucas, 1858) and Opisthacanthus africanus Simon, 1876 [Pocock, 1896; Lourenço, 1981, 1982]). However, a precise knowledge of the scorpion fauna of Cameroon is still far from being achieved.

Among the scorpion groups distributed in this region of Africa, the genus Babycurus appears to be one of the most complex and the identity of several species remained dubious for a long time. For instance, Lourenço [1986] studied large collections from the LAMTO Ecological Station in Côte d'Ivoire and concluded that the local Babycurus population present there could be identified as B. kirki (Pocock, 1890), simultaneously rejecting the synonymy of this species with Babycurus buettneri Karsch, 1886 which had been proposed by Kraepelin [1899]. This decision, however, was not taken in consideration in the Catalog of the scorpions of the world [Fet \& Lowe, 2000].

In a revision of the genus Babycurus Karsch, 1886, Kovařík [2000] maintained the validity of both $B$. buettneri and $B$. kirki, but suggested the synonymy of $B$. johnstonii with $B$. buettneri and confirmed the synonymy of Babycurus neglectus Kraepelin, 1896 with $B$. kirki. Shortly after that, Prendini [2004], in a rather complete study concerning the scorpions of Gabon and neighbouring countries, confirmed the synonymy of $B$. kirki with $B$. buettneri, but restored both $B$. johnstonii and $B$. neglectus as valid species. In a subsequent ecological study on the scorpions of the LAMTO Ecological Station, Lourenço et al. [2005] confirmed the taxonomic status of the local Babycurus population as distinct and described a new subspecies as Babycurus buettneri savanicola Lourenço, Ramos et CloudsleyThompson, 2005.

Prendini [2004] listed a total of nine species from Cameroon, one of which, Isometrus maculatus (DeGeer, 1778), is an introduced species from Asia. The other eight are five buthid species, two liochelid and one scorpionid. All these species, however, are mainly located in the southern parts of Cameroon dominated by tropical rain forest and more mesic conditions. It was not until quite recently that the first, new species was described from northern Cameroon: Leiurus savanicola Lourenço, Qi et Cloudsley-Thompson, 2006 [Lourenço et al., 2006], to be followed by the descriptions of Scorpio savanicola Lourenço, 2009 [Lourenço, 2009] and Buthus prudenti Lourenço et Leguin, 2012 [Lourenço \& Leguin, 2012]. All these species live in similar habitats within the savannah/sahel formations of northern Cameroon.

In the present contribution, a new species belonging to the genus Babycurus is described from these 


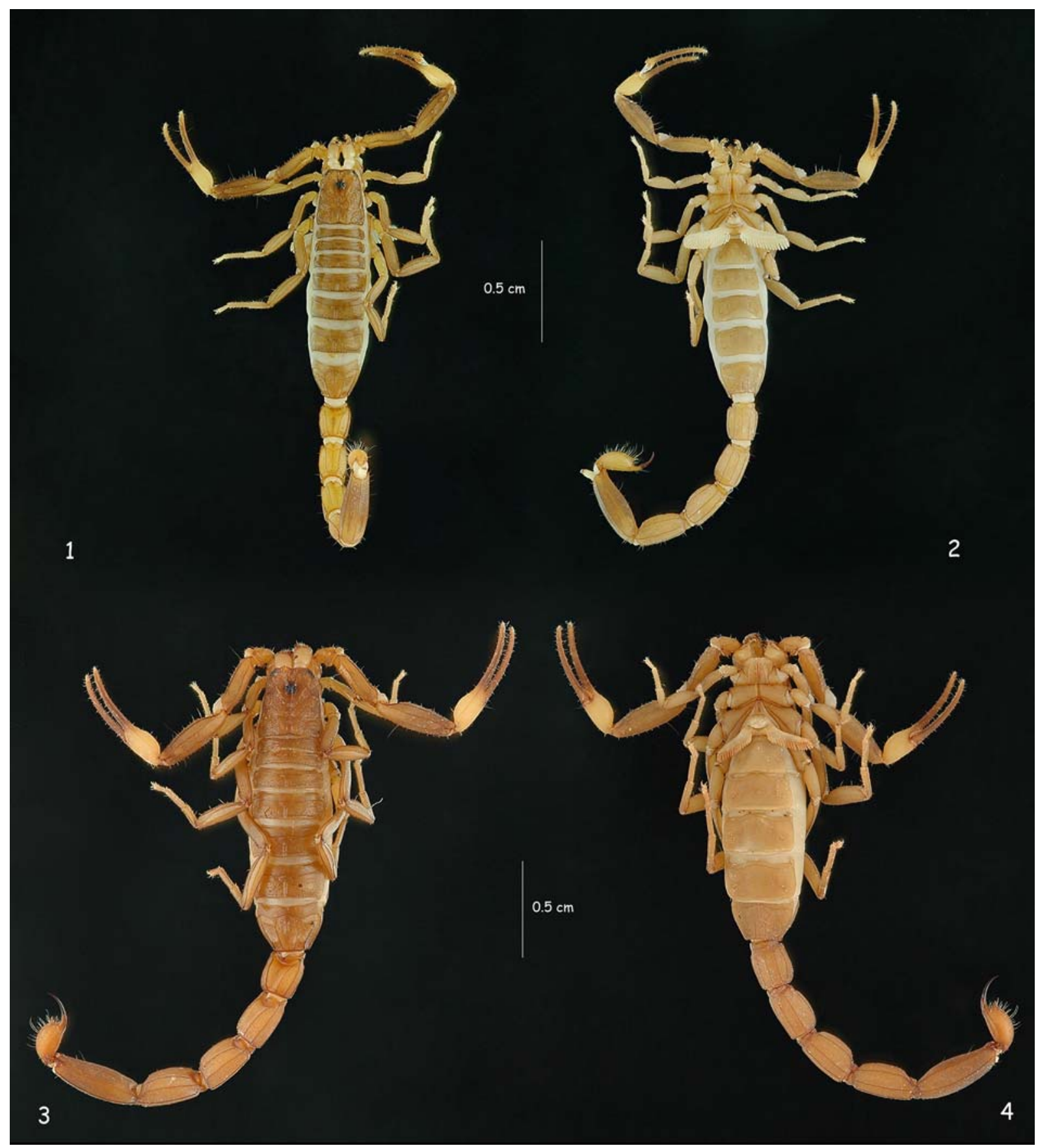

Figs 1-4. Babycurus prudenti sp.n., $0^{7}$ holotype (1-2) and + paratype (3-4). Habitus, dorsal and ventral aspects, respectively. Рис. 1-4. Babycurus prudenti sp.n., голотип О7 (1-2) и паратип + (3-4). Внешний вид соответственно сверху и снизу.

savannah/sahel formations of northern Cameroon. The discovery of this new species attests to the understudied scorpion richness of this area.

\section{Material and methods}

The holotype and four paratypes are deposited in the Muséum national d'Histoire naturelle, Paris
(MNHN). Two paratypes have been shared with the collections of the CIRAD, UMR CBGP (INRA/IRD/ Cirad/Montpellier SupAgro). One paratype is donated to the Zoological Museum, State University of Moscow, Russia (ZMUM). Scorpions were collected in cotton fields with the use of Barber traps. Illustrations and measurements were made with the aid of a Wild M5 stereo-microscope equipped with a drawing tube 


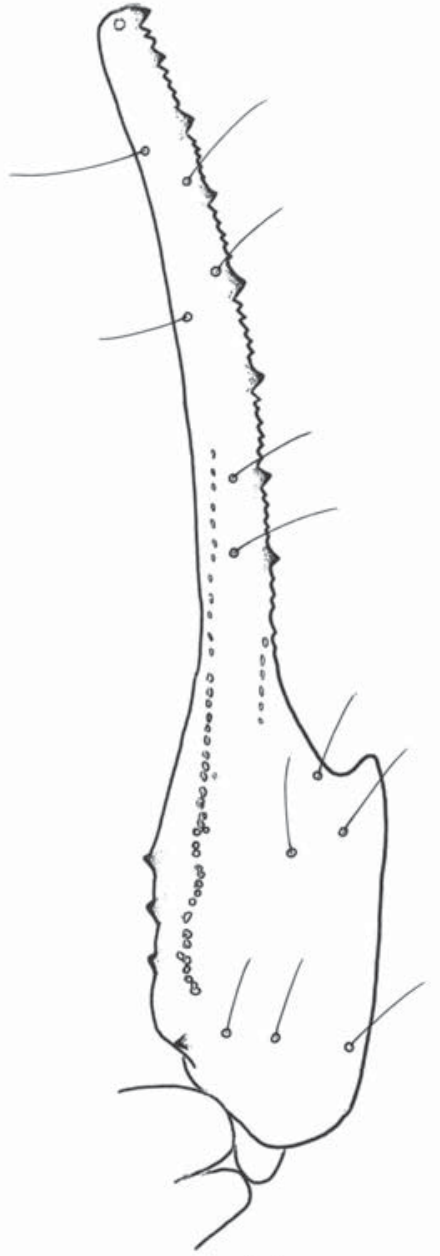

5
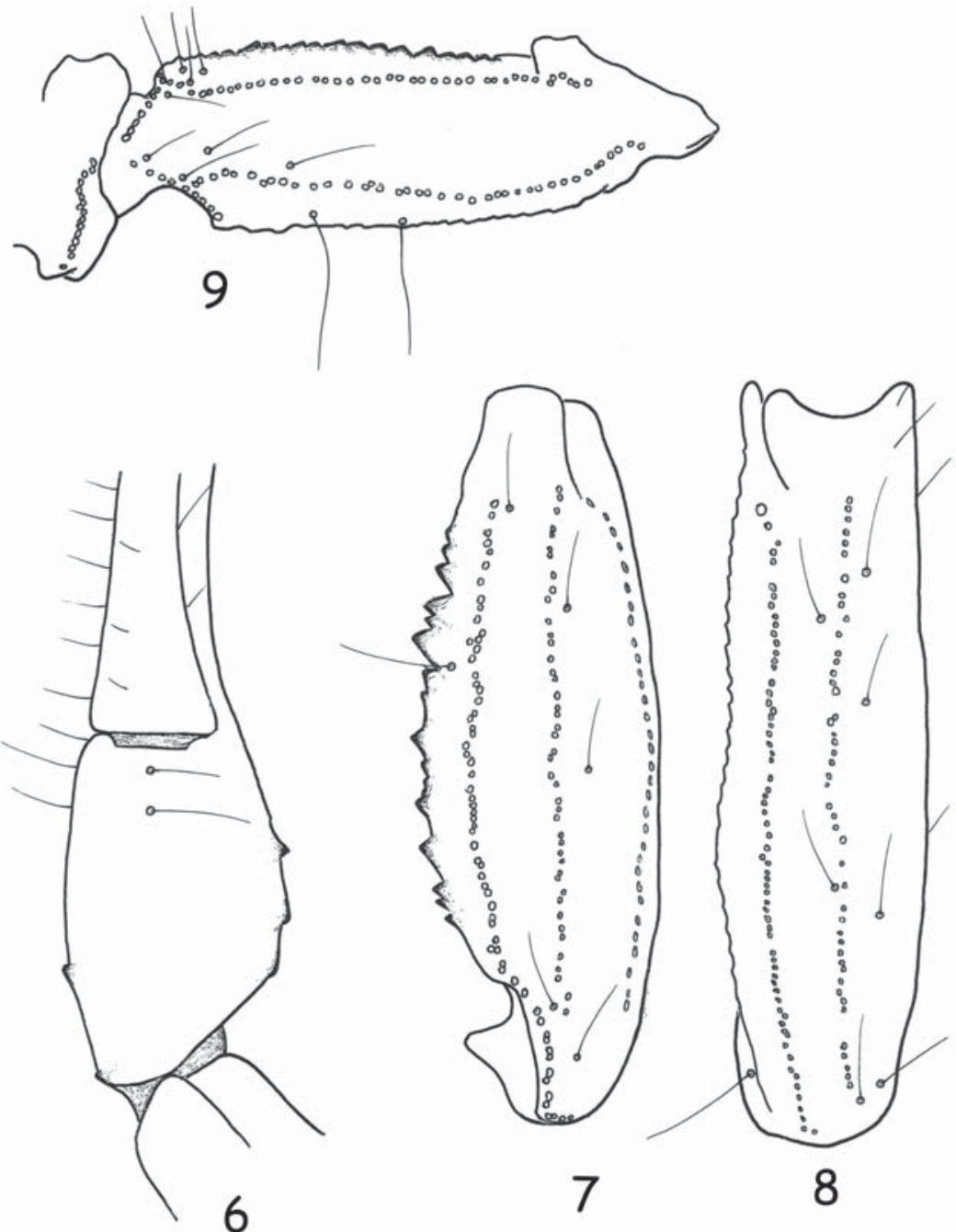

Figs 5-9. Babycurus prudenti sp.n., + paratype, trichobothrial pattern: 5-6 - chela, dorso-external and ventral aspects, respectively; 7-8 - patella, dorsal and external aspects, respectively; 9 - femur, dorsal aspect.

Рис. 5-9. Babycurus prudenti sp.n., паратип +, размещение трихоботрий: 5-6 - хела, соответственно сверху и снаружи, а также снизу; 7-8 - пателла, соответственно сверху и снаружи; 9 - фемур, сверху.

(camera lucida) and an ocular micrometer. Measurements follow Stahnke [1970] and are given in mm. Line drawings and photographs are not executed to scale. Trichobothrial notations follow Vachon [1974] while morphological terminology mostly follows $\mathrm{Va}$ chon [1952] and Hjelle [1990].

\section{Taxonomic part}

Family Buthidae C.L. Koch, 1837

Genus Babycurus Karsch, 1886

\section{Babycurus prudenti sp.n.}

Figs 1-14.

HOLOTYPE $\sigma^{\top}$ (MNHN), Cameroon, Garoua, region of Sanguéré-Djoï $\left(9^{\circ} 13^{\prime} 52.4^{\prime \prime} \mathrm{N}, 13^{\circ} 30^{\prime} 3.2^{\prime \prime} \mathrm{W}\right)$. Paratypes: 1 †, $2 \bigcirc^{7} \sigma^{7}, 1$
$\mathrm{O}^{7}$ juv. (MNHN); 1 $+1 \mathrm{O}^{\top}$ juv. (CIRAD); 1 (ZMUM). SanguéréDjoï, Gaschiga $\left(9^{\circ} 28^{\prime} 5.5^{\prime \prime} \mathrm{N}, 13^{\circ} 19^{\prime} 52.5^{\prime \prime} \mathrm{W}\right)$, Guilder $\left(10^{\circ} 00^{\prime} 34.1^{\prime \prime} \mathrm{N}\right.$, $\left.13^{\circ} 54^{\prime} 58.2^{\prime \prime} \mathrm{W}\right)$, Kismatari-Tajetes and Tcholliré $\left(8^{\circ} 27^{\prime} 24.5^{\prime \prime} \mathrm{N}\right.$, $\left.14^{\circ} 15^{\prime} 44.9^{\prime \prime} \mathrm{W}\right)$, August/October 2012, leg. P. Prudent. Scorpions collected with Barber traps.

NAME. Honors Dr. Patrick Prudent, CIRAD/IRAD, Garoua, Cameroon, who collected the material described here.

DIAGNOSIS. Scorpions of small size in relation to the other species of the genus, reaching a total length of $24.5 \mathrm{~mm}$ for $O^{7} \mathrm{O}^{7}$ and $31.7 \mathrm{~mm}$ for 0 + . General coloration golden-yellow to orange-testaceous with infuscations on pedipalp patella and metasomal segment $\mathrm{V}$. Carinae and granulations weak to moderate. Fixed and movable fingers with 6 or 7 rows of granules. Pectines with 15 to 16 teeth in both sexes.

RELATIONSHIPS. By its general morphology, Babycurus prudenti sp.n. shows some affinities with 


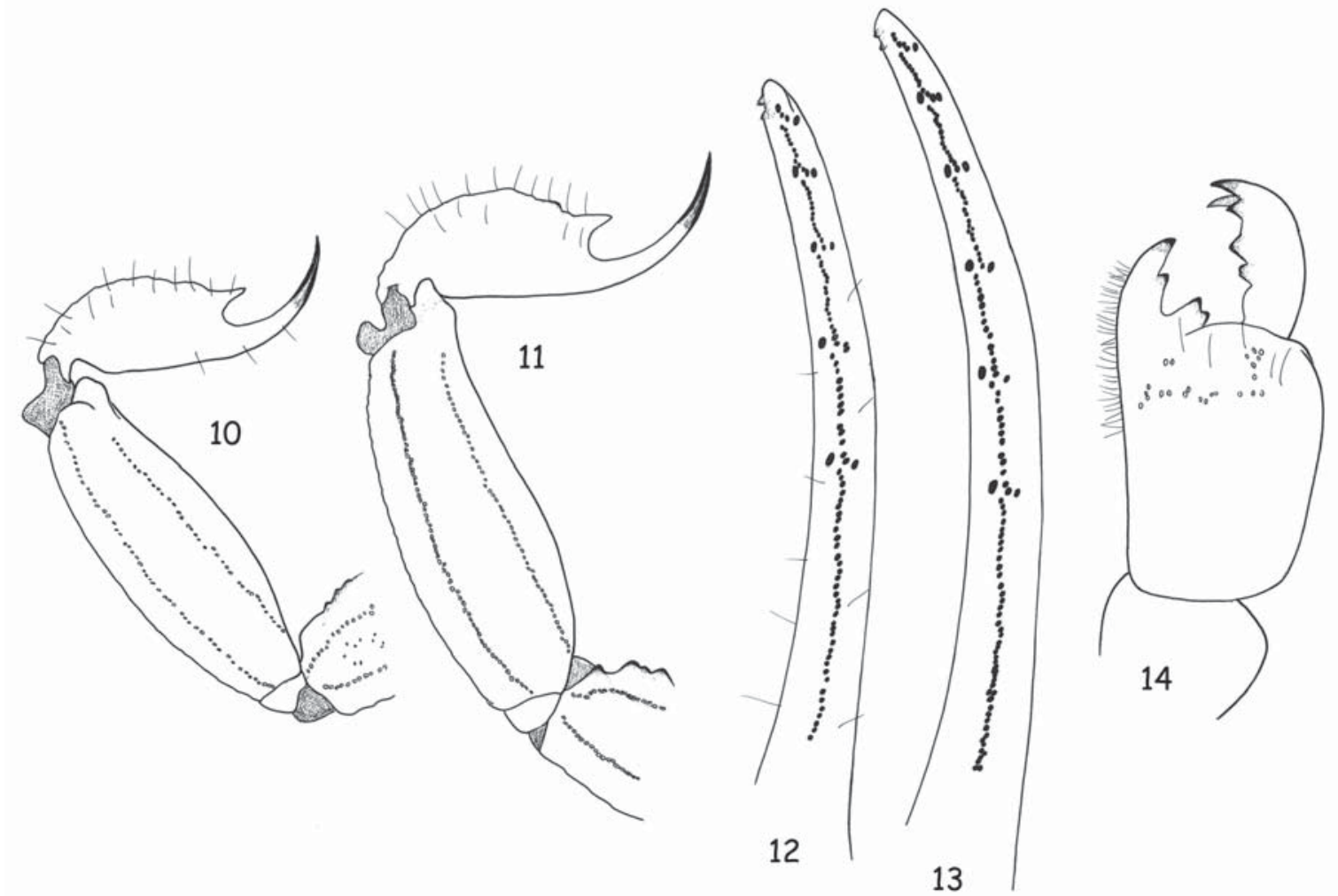

Figs 10-14. Babycurus prudenti sp.n.: 10-11 - metasomal segment $\mathrm{V}$ and telson in $0^{7}$ (holotype) and $q$ (paratype), respectively, lateral aspect; $12-13-$ movable finger of pedipalp chela with rows of granules in $\sigma^{7}$ (holotype) and + (paratype), respectively; $14-$ chelicera (holotype).

Рис. 10-14. Babycurus prudenti sp.n.: 10-11 - сегмент V метасомы и тельсон соответственно у о (голотип) и + (паратип), сбоку; 12-13 - подвижный палец хелы педипальп с рядами гранул соответственно у О (голотип) и + (паратип); 14 - хелицера (голотип).

Babycurus ugartei Kovařík, 2000, a species described from Nigeria. It can, however, be distinguished from that species by a number of characters: (i) a different pattern of body coloration, golden-yellow to orangetestaceous without any spots on the carapace, tergites and legs, (ii) a very weakly marked carination on sternite VII, (iii) tibial spurs reduced and only present on leg IV of the + , absent from the $O^{7}$. Moreover, although both species can be considered related geographically, they live in quite distinct habitats (see Ecological notes).

DESCRIPTION. Based on holotype and paratypes. Morphometric measurements are listed after the description.

Coloration. Body golden-yellow to orange-testaceous (Figs 1-4). Prosoma: carapace orange-testaceous without spots; eyes surrounded by black pigment. Mesosoma: yellowish to orange-testaceous without any dark bands. Metasomal segments orange-testaceous; segment V with some vestigial fuscosity; vesicle yellowish; aculeus yellowish with a reddish tip. Venter pale yellow. Chelicerae yellowish with a vestigial variegated pigmentation in $\sigma^{7}$, without any pigmentation in $P$; fingers and teeth reddish. Pedipalps yellowish with some vestigial fuscosity on femur, patella and chela fingers; rows of granules on fingers reddish. Legs pale yellow overall.

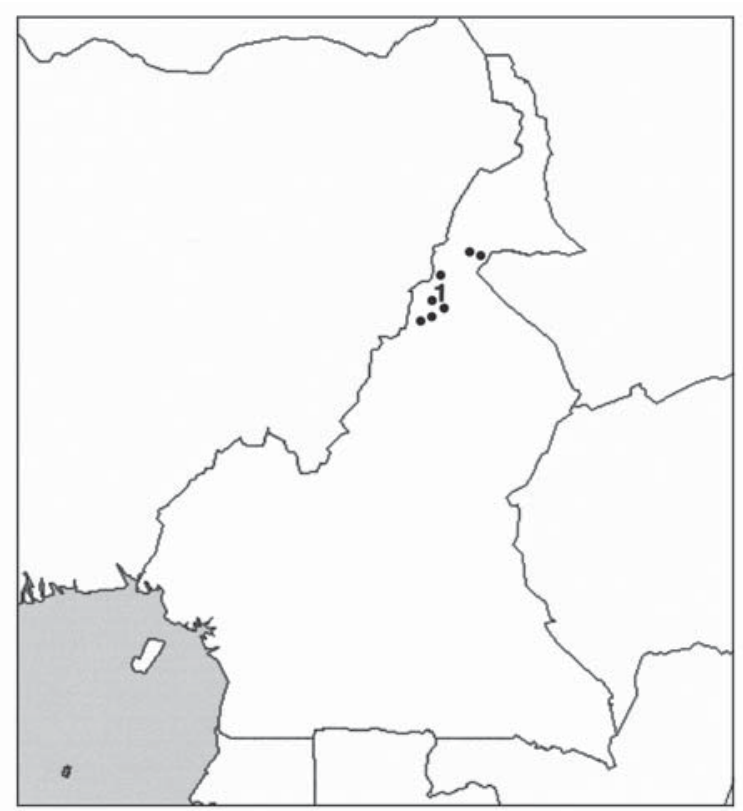

Fig. 15. Map of northern Cameroon, showing the collection localities of Babycurus prudenti sp.n. (black circles) around the town of Garoua (1).

Рис. 15. Карта Северного Камеруна, показывающая точки сбора Babycurus prudenti sp.n. (черные кружки) вокруг города Гаруа (1). 


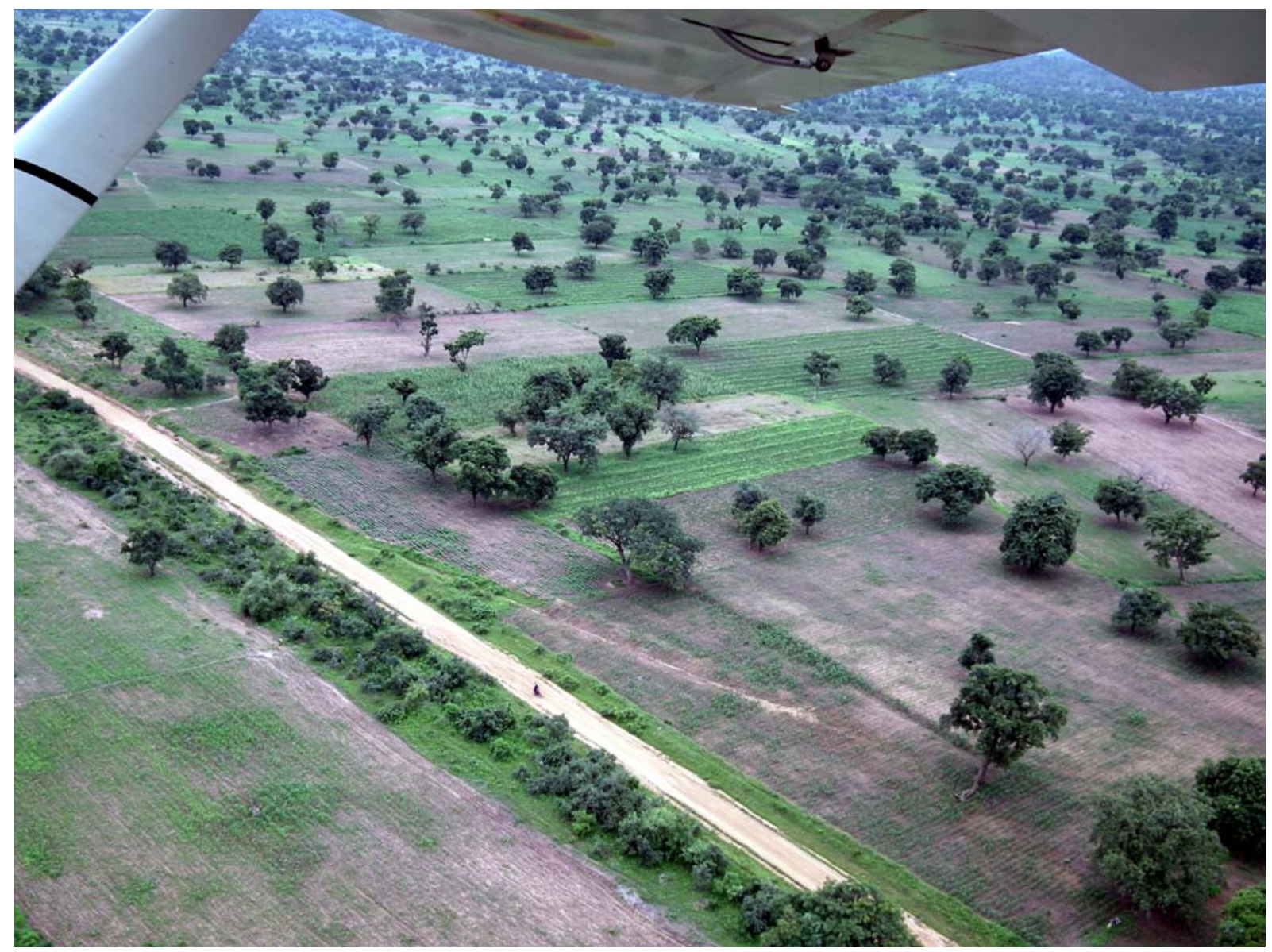

Fig. 16. Aerial view of the Sanguéré-Djoï-Gaschiga region, showing the typical savannah/sahel vegetation. Photo courtesy of FrançoisRégis Delobal.

Рис. 16. Вид с воздуха района Сангере-Джои-Гасшига, показывающий типичную растительность саванны и сахеля.

Structure. Carapace moderately granular; anterior margin with a very weak concavity, almost straight; carinae weak to obsolete; furrows weak. Median ocular tubercle anterior to centre of carapace; median eyes separated by 1.5 ocular diameters. Three pairs of lateral eyes. Sternum triangular. Mesosoma: tergites with a weak granulation. Median carina weak to moderate in all tergites. Tergite VII pentacarinate, but all carinae moderately marked. Venter: genital operculum divided longitudinally, forming two semi-triangular plates. Pectines: pectinal tooth count 16-16 in holotype; $16-15$ in a 9 paratype; basal middle lamellae of each pecten not dilated. Sternites smooth with weakly elongate spiracles; VII with vestigial carinae. Metasoma: segments I with ten carinae; segments II to IV with eight carinae; segment V with five carinae; all carinae moderately marked (Figs 10 \& 11). Tegument weakly granular. Telson with rough granules ventrally; other surfaces smooth; presence of a moderate setation; aculeus shorter than vesicle and strongly curved; subaculear tooth strong and spinoid. Cheliceral dentition characteristic of the family Buthidae [Vachon, 1963]; basal teeth on movable finger small and fused (Fig. 14); ventral aspect of both finger and manus with long dense setae. Pedipalps: femur pentacarinate, crenulate; patella with seven carinae, crenulated; internal face of patella with 5-8 spinoid granules; chela with some vestigial carinae; all faces smooth. Fixed and movable fingers with 6 or 7 almost linear rows of granules; internal and external accessory granules present (Figs $12 \&$ 13). Trichobothriotaxy (Figs. 5-9) A- $\beta$, orthobothriotaxy [Vachon, 1974, 1975]. Legs: tarsi with numerous fine setae ventrally. Tibial spurs reduced and only present in leg IV of ${ }_{+}$; absent from legs III and IV in $O^{7}$; pedal spurs present in all legs.

Morphometric values (in $\mathrm{mm}$ ) of $\sigma^{7}$ (holotype) and + (a paratype). Total length (including telson) 24.5/ 31.7. Carapace: length 2.6/3.5; anterior width 1.7/2.4; posterior width 2.4/3.3. Mesosoma length 7.1/9.7. Metasomal segment I: length 1.6/2.0, width 1.4/2.0; II: length $2.0 / 2.5$, width $1.3 / 1.8$; III: length $2.2 / 2.7$, width $1.3 /$ 1.7; IV: length $2.6 / 3.2$, width $1.3 / 1.8$; V: length $3.6 /$ 4.4, width $1.2 / 1.7$, depth $1.2 / 1.7$. Telson length $2.8 /$ 3.7. Vesicle: width $0.9 / 1.3$, depth 1.0/1.2. Pedipalp: femur length $2.4 / 3.4$, width $0.8 / 1.1$; patella length $3.1 /$ 4.2 , width $0.9 / 1.3$; chela length $4.3 / 6.1$, width $0.8 / 1.1$, depth $0.8 / 1.2$; movable finger length 3.1/4.2. 


\section{Ecological notes}

The area in which Babycurus prudenti sp.n. has been collected is the transitional zone between the sahel and savannah formations (Fig. 16). Most of these natural formations have been replaced in the recent years by agriculture. The types of new species were taken from cotton fields with 'Barber traps' used to test the efficacy of chemical treatments on seeds. At the present, most of the Senguéré-Djoï area is also used for agriculture, however some bushes can also persist (Fig. 15).

A few other scorpion species have also been collected in the region of northern Cameroon. Very recently, Buthus prudenti Lourenço et Leguin, 2012 was described from this area. That species seems to be an opportunistic (generalist) element since its density appears to be very high and apparently its populations are expanding and colonizing most of the area [Lourenço \& Leguin, 2012]. In the past, when large parts of the natural environment were still intact, two other species were collected: Leiurus savanicola Lourenço, Qi et Cloudsley-Thompson, 2006 and Scorpio savanicola Lourenço, 2009 [Lourenço et al., 2006; Lourenço, 2009]. It is quite possible, however, that with the increasing anthropogenic pressure on the environment, most of the scorpion species will experience a significant regression of their population numbers and distributions.

In contrast, according to Kovařík [2000], Babycurus ugartei was collected in Plateau Lafia, Nigeria. Lafia is a Nigerian town located in the Nassarawa State which is at the frontier to the Plateau State. This central area of Nigeria supports numerous plateaus where the climatic conditions are more mesic and the vegetation is much denser than what is currently observed in northern Cameroon [Akosim et al., 2007].

ACKNOWLEDGEMENTS. I am most grateful to Dr. Patrick Prudent, CIRAD/IRAD, Garoua, Cameroon, for sending the material for study and for sharing information about the ecology and habitat of the new species, to Michael M. Webber, University of Nevada, Las Vegas for her review of an earlier version of the manuscript, to Elise-Anne Leguin (MNHN) for her assistance with the preparation of the photos and plates, and to Dr. Sergei Golovatch, Russian Academy of Sciences, Moscow for his interest in the publication of this article.

\section{References}

Akosim C., Kwaga B.T., Ali A., Mamman G.S. 2007. Flora resources and structure in Pandam Wildlife Park, Pandam, Plateau State, Nigeria // Agriculture Journal. Vol.2. P.740-747.

Fet V., Lowe G. 2000. Family Buthidae C.L. Koch, 1837 // Fet V., Sissom W.D., Lowe G. \& Braunwalder M.E. (eds.). Catalog of the scorpions of the world (1758-1998). New York: The New York Entomological Society. P.54-286.
Hjelle J.T. 1990. Anatomy and morphology // Polis G.A. (ed.). The Biology of Scorpions. Stanford: Stanford Univ. Press. P.9-63.

Kovařík F. 2000. Revision of Babycurus with descriptions of three new species (Scorpiones: Buthidae) // Acta Societatis Zoologicae Bohemoslovenicae. T.64. P.235-265.

Kraepelin K. 1899. Scorpiones und Pedipalpi // Dahl F. (Hrsg.) Das Tierreich. Herausgegeben von der Deutschen zoologischen Gesellschaft. Berlin: R. Friedländer und Sohn Verlag. 265 S.

Lourenço W.R. 1981. A propos de la désignation d'un néotype pour Opisthacanthus lecomtei (Lucas, 1858) (Scorpiones, Scorpionidae) // Bulletin du Muséum national d'Histoire naturelle, Paris. 4e sér. T.3. P.1163-1168.

Lourenço W.R. 1982. Redécouverte de l'holotype d'Opisthacanthus africanus Simon, 1876 (Scorpiones, Scorpionidae) // Revue Arachnologique. T.3. P.147-153.

Lourenço W.R. 1986. Les scorpions de la Station Ecologique de LAMTO (Cote d'Ivoire) // Bulletin du Muséum national d'Histoire naturelle, Paris. 4e sér. T.8. P.199-208.

Lourenço W.R. 2009. Reanalysis of the genus Scorpio Linnaeus 1758 in sub-Saharan Africa and description of one new species from Cameroon (Scorpiones, Scorpionidae) // Entomologische Mitteilungen aus dem Zoologischen Museum Hamburg. Bd.15. S.99-113.

Lourenço W.R., Bruehmueller Ramos E.C., Cloudsley-Thompson J.L. 2005. Further notes on the scorpions inhabiting the savannas of the Lamto Ecological Station in Côte d'Ivoire // Entomologische Mitteilungen aus dem Zoologischen Museum Hamburg. Bd.14. S.253-263.

Lourenço W.R., Leguin E.-A. 2012. A new species of the genus Buthus (Scorpiones: Buthidae) from Northern Cameroon // Euscorpius. T.152. P.1-9.

Lourenço W.R., Qi J.-X., Cloudsley-Thompson J.L. 2006. The African species of the genus Leiurus Ehrenberg, 1828 (Scorpiones: Buthidae) with the description of a new species // Boletin de la Sociedad Entomológica Aragonesa. T.39. P.97-101.

Pocock R.I. 1896. On the scorpions, centipedes and millipedes obtained by Dr. Gregory on his expedition to Mount Kenia, East Africa // Annals and Magazine of Natural History. Ser.6. Vol.17. P.425-444.

Prendini L. 2004. On the scorpions of Gabon and neighboring countries, with a reassessment of the synonyms attributed to Babycurus buettneri Karsch and a redescription of Babycurus melanicus Kovařík // California Academy of Sciences Memoir. Vol.28. P.235-267.

Stahnke H.L. 1970. Scorpion nomenclature and mensuration // Entomological News. Vol.81. P.297-316.

Vachon M. 1952. Etudes sur les scorpions. Alger: Publications de 1'Institut Pasteur d'Algérie. 482 p.

Vachon M. 1963. De l'utilité, en systématique, d'une nomenclature des dents des chélicères chez les Scorpions // Bulletin du Muséum national d'Histoire naturelle, Paris. 2e sér. T.35. P.161-166.

Vachon M. 1974. Etude des caractères utilisés pour classer les familles et les genres de Scorpions (Arachnides). 1. La trichobothriotaxie en arachnologie. Sigles trichobothriaux et types de trichobothriotaxie chez les Scorpions // Bulletin du Muséum national d'Histoire naturelle, Paris. 3e sér. T.140. P.857-958.

Vachon M. 1975. Sur l'utilisation de la trichobothriotaxie du bras des pédipalpes des Scorpions (Arachnides) dans le classement des genres de la famille des Buthidae Simon // Comptes Rendus de 1'Académie des Sciences, Paris. Sér.D. T.281. P.15971599 . 